D. I. Weber

\title{
PAMPHLET AS A MEANS OF A PROPAGANDA IN BALTIC REGION IN EARLY MODERN TIME
}

The article describes the context in which Caspar von Münster wrote his pamphlet (the so-called "Verteidigungsschrift"). The author was landmarshal of the Teutonic Order in Livonia. It was published in 1556 during the time of the so-called "Coadjutors' War". Attention is paid not only to the context of the creation of this source and its author, but to pamphlet's publisher. The fact that it was Johann Daubmann, a typographer of the Prussian Duke Albrecht of Brandenburg-Ansbach, emphasizes the connection between the publication of pamphlets and political interests of the rulers of the neighbouring lands of the Order in Livonia, for example the Duke of Prussia, the King of Poland and Grand Duke of Lithuania. This pamphlet showed internal conflicts in the Teutonic order. A lesser part of this article directs attention to the dating of pamphlet publication. One part of this pamphlet was a letter was written by the landmarshal to the Livonian landmaster Heinrich von Galen. Identified copies of this letter provoke further questions. The first question is about two copies in the archives of the Duke of Prussia. It was made before sending the letter to the Landmaster. Was one of these Münster's draft document, which he later may have given to the Duke of Prussia, and then later to the press? Not less important is the answer to the question of whether this pamphlet drew a wide response or not. One reason for this question is the publication in 1557 of a pamphlet in Daubmann's printing press, but in Latin. Refs 37.

Keywords: Caspar von Münster, Teutonic order, “Coadjutors' war”, Johann Daubmann, Heinrich von Galen.

For citation: Weber D. Pamphlet as a means of a propaganda in Baltic region in early modern time. Vestnik of Saint Petersburg University. History, 2017, vol. 62, issue 2, pp. 291-298. DOI: 10.21638/11701/spbu02.2017.206

Д. И. Вебер

\section{ПАМФЛЕТ КАК СРЕДСТВО ПРОПАГАНДЫ В ПРИБАЛТИКЕ В РАННЕЕ НОВОЕ ВРЕМЯ}

В статье рассматривается контекст создания памфлета, автором котором является Каспар фон Мюнстер, ландмаршал Немецкого ордена в Ливонии. Памфлет был написан в 1556 г. в условиях так называемой «войны коадъюторов». Внимание уделено не только контексту создания источника и его автору, но и издателю памфлета. Тот факт, что им стал Иоганн Даубманн, типограф, приближенный к герцогу Прусскому Альбрехту Бранденбург-Ансбахскому, подчеркивает связь между изданием памфлета и политическими интересами правителей земель, соседних с владениями Ордена в Ливонии, - не только герцога Прусского, но также короля Польши и великого князя Литовского. Их заинтересованность в фигуре Каспара фон Мюнстера определялась тем, что с его помощью можно было дестабилизировать обстановку не только в Ливонской конфедерации, но и внутри Ордена, поскольку данный памфлет отражал внутренние противоречия в корпорации. В рамках статьи затрагиваются источниковедческие проблемы, связанные с созданием памфлета. Одну из частей памфлета составляет письмо, написанное автором ливонскому ландмайстеру Генриху фон Галену. Выявленные копии этого письма позволяют задать несколько вопросов: каким образом эти две копии попали в архив герцога, делалась ли копия перед отправкой письма ландмайстеру или у Мюнстера был

Weber Dmitriy Ivanovich - PhD of History, St. Petersburg State University, 7-9, Universitetskaya nab., St. Petersburg, 199034, Russian Federation; d.veber@spbu.ru

Вебер Дмитрий Иванович - кандидат исторических наук, Санкт-Петербургский государственный университет, Российская Федерация, 199034, Санкт-Петербург, Университетская наб., 7-9; d.veber@spbu.ru

The publication was prepared with the support of the grant of Russian Foundation for Humanities № 15-31-01009 project "The press and communicative practices of confessional era: Central Europe and Baltics".

(C) Санкт-Петербургский государственный университет, 2017 
черновик, который он позже предоставил в распоряжение герцога для снятия копии, а позже и типографу? Не менее важен и ответ на вопрос, вызвал ли данный памфлет какой-либо резонанс. Одной из причин, побуждающих задавать его, является публикация в 1557 г. памфлета Мюнстера в той же типографии Даубманна, но на латинском языке. Возникает и ряд других вопросов, ответы на которые будут даны в ходе дальнейших исследований. Библиогр. 37 назв. Ключевые слова: Каспар фон Мюнстер, Немецкий орден, Иоганн Даубманн, война коадъюторов, Ливония, Генрих фон Гален.

The sixteenth century which is simultaneous with Early Modern period is marked, as we know, by printing development. For us, however, of greater interest is not this phenomenon in itself, but its use in political conflicts and for propaganda purposes, its communications with printing house where it was created.

Besides, it is possible to raise the point of some historiographic questions. The composition is devoted to the article "Warhafftiger, kurtzer und wolgegründter bericht, des Ehrwirdigen.... Herren Caspar v. Münster, Teutsches Ordens Landtmarschalchs zu Leyfflan$d t$..." Its author, as the title indicates, is Caspar von Münster, a landmarshal of the Teutonic Order in Livonia. The interest in this source is prompted by the fact, that it allows us to see plainly the contradictions within the Order. Besides, new archival findings allow us to address additional questions to this source.

One of the copies of this source was found in the Main Land archive of Schwerin (Germany, the Federal State of Mecklenburg-West Pomerania), in the fund 02.11.02/1 which contains the correspondence of dukes of Mecklenburg concerning the events in Livonia. This fund has drawn our attention because Christophe of Mecklenburg, whose election as a coadjutor bishop of the archbishop of Riga led to the beginning of military conflict in Livonia, was related to the duke: the pamphlet about him is preserved under the reference number 02.11.02/1 009 (1063). The finding of the pamphlet gave rise to further research, including searches of other copies, mainly, because the one discovered is not absolutely complete. The source is a part of convolute which consists also of dukes' of Mecklenburg correspondence concerning Livonia. Inside the convolute the pamphlet pagination is broken in some places. This copy was mentioned by A. Bergengrün in a work about Christophe of Mecklenburg [Bergegrün 1898, p. 55]. The first publication of the source was also mentioned there.

It was published by Julius von Bohl in 1865 [Bohl 1865, pp. 143-160]. As judged by the footnote on the Mitteilungen aus dem Gebiete der Geschichte ... [Bohl 1865, p. 143] ${ }^{1}$, it is possible to suppose that the copy from the Teutonic Order Archive in Koenigsberg was taken as its basis. However, after World War II not many documents from this archival corpus remained intact. At least, we have not managed to reveal any remains of this pamphlet in the Secret archive of Prussian cultural heritage (Geheimes Staatlisches Archiv Preußisscher Kulturbesitz) yet. However, two copies which preserved its integrity were found. The first one is in the Bavarian State Library, under the code Res/4 Biogr. 280,17. It is important to note that another one is in St. Petersburg. It is available in the National Library of Russia in Rossika department, under the code 13.6.2.173, and in the Microfilm Collection Mf of K-3/15231. It contains 20 sheets, $4^{\circ}$ and $18 \mathrm{~cm}$ high. There are no watermarks. The pamphlet at issue is of great research interest, as it was published in the context of a political conflict in the Livonian confederation in 1556, which reflected plainly on the contradictions between landlords

${ }^{1}$ I would like to express my gratitude to Dr. Juhan Kreem for this information. 
in the name of archbishop of Riga and the Livonian branch of the Teutonic Order, as well as the contradictions inside the chivalric order. In 1553 the duke of Mecklenburg sent the archbishop of Riga a message with request to support his brother Christophe, appointing the latter as his coadjutor [Rasmussen 1973, pp. 30-32]. In February, 1554 the archbishop set the seal on this. During the next year and a half he managed to get support of the emperor Charles V, of the Roman curia and of the princes of the Holy Roman Empire [Rasmussen 1973, pp. 30-32]. This emplacement contradicted the resolution of the Wolmar Landtag of 1546 , according to which a representative of hereditary aristocracy couldn't be appointed as the coadjutor or the bishop [Hiärn 1835, p. 201]. These events led to growing animosity with the Duchy of Prussia and with Poland, because the archbishop of Riga was Albrecht of Brandenburg - Ansbach's brother, and was also related of the Polish king. In particular, on September 1, 1555 at another meeting, Albert Sigismund II promised to give Christophe full support [Popov, Filyushkin 2009, p. 152]. In January, 1556 this question was discussed at the meeting of convention in Wenden, where it was proclaimed that only the Livonian diet, which had been convened in Valmiera on March 8, 1556, had the right to approve or reject the candidate. There was a question at play there - about Christophe of Mecklenburg as a coadjutor [Monumenta Livoniae Antiquae 1847, pp. 667-668]. Unlike the Order, the clergy gave support to the archbishop and to the new coadjutor. A compromise was reached Christophe was declared a coadjutor, but his powers were limited. The main ones were: prohibition to marry, to defrock, to laicize the archbishopric, to hold any other positions, except being a coadjutor, to make pacts with the Crown of the Kingdom of Poland, to act to the detriment of the Livonia independence and others. [Rasmussen 1973, p.50]. Nevertheless, the Order was not pleased with Christophe of Mecklenburg's candidacy. Military clashes [for more details about "war of coadjutors" see: Kreem 2014, p. 73; Hartmann 2004, pp. 275-307; Popov Filyushkin 2009, pp. 151-185; Mol 2014, pp. 205-240; Olewnik 1979, pp. 393-408; Weber 2014, pp. 211-232, Bessudnov 2015, pp. 147-152 etc.].

This conflict showed contradictions not only in Livonia at large, but inside the corporation of the chivalric order, having adopted as its active participant the author of the pamphlet mentioned above, Caspar von Münster, a landmarshal of the Livonian Order. A landmaster also needed a coadjutor. Christoph Neuhoff, the commander of Goldingen, Caspar von Münster, a landmarshal of the Livonian Order and Wilhelm von Fürstenberg, the commander of Fellin (today Viljandi) aspired to this position. The latter got the coadjutor's position, in view of von Münster's pro-Polish views. It was violation of tradition, as it was a ladmarshal who had to get this appointment, which caused a split in the Order. Perhaps, Fürstenberg's appointment in opposition to Wilhelm von Brandenburg was connected with the opposition between them [Popov, Filyushkin 2009, p. 155]. In consequence of these events landmarshal von Münster had gone to Prussia where he created a party against the landmaster [Merkel 1807, p. 39]. According to Renner, the archbishop of Riga sent the message to the King of Poland, Sigismund Augustus, who later expressed concern about von Münster's destiny [Renner 1953, p. 11].

The exact year of birth of the pamphlet's author is unknown. Caspar (Jasper) von Münster was born in Duursum castle in Frisland (in Drentse), in a family of ministerialis under the bishop [Fenske Militzer 1993, p. 460]. The Münster family traditionally sent their children to the Livonian Order from the $13^{\text {th }}$ century, so in 1515 , at the age of 14-15 years, Caspar was sent to the service. The first years of his service is an unknown period, however, in 1538 Caspar von Münster held a schaffer's position in Wenden, thus 
opening a way to the landmaster's suite. In 1540 he became a commander of Marienburg, and in 1551 a landmarshal. As Caspar was not well-born, we have an opportunity to believe that he managed to build so serious career in the Order only thanks to his character which allowed him to make the way from the unknown descendant of a noble family to one of Livonia's heavyweights.

As noted by J. Mol, in spite of the fact that Caspar von Münster is a prominent figure in the history of Livonia of the $16^{\text {th }}$ century, his activity has evaded thorough examination. Perhaps, this is an influence of the Baltic-German historiographic tradition influence. He had been appointed to a position of the Order's landmarshal in 1551 because two of his predecessors subsequently became landmasters; he could be considered as a figure aspiring to a dominating position [Mol 2011, p.236].

Landmarshal Caspar von Münster became one of the opponents of the Order's policy. On the Wolmar Landtag of 1556 he spoke out of advancing contact with the Livonian Order's political rival, the Polish-Lithuanian Commonwealth [Hartmann 2004, p. 288]. According to him, Livonia could remain, entering into rime-proof alliance with the Polish-Lithuanian Commonwealth. Just after the Landtag von Münster was accused of treason and was removed from his post. He tried to pursue this policy between 1554 and 1556, but he did not find enough support. He was accused of treason and ran to Lithuania, returning in the 1560 s to Ascheraden castle.

The conflict began to escalate in May 1556, when von Münster attempted to occupy Dünamünde [Olewnik 1979, pp. 396-397]. On May 10 he sent Sigismund a letter in cipher, asking for military assistance, but, as it appears from the Livonian Chronicle of Grefenhal, it went astray [Monumenta Livoniae Antiquae 1847, p. 126]. The same is evidenced by Baltasar Russov: “... the archbishop was talking with the landmarshal, Caspar von Münster, how to put all Livonia under the patronage of the King of Poland" [Russow 1845, p. 170]. Also, the chronicler noted the possibility of a religious dimension, since he, by the time of the conflict, had been already an adherent the of evangelical faith (Russow 1845, p. 171]. These contacts with Poland and the Duke of Prussia aroused displeasure and, as a consequence, accusations of treason, which probably motivated the publication of Münster's "defense letter".

Within this article we are interested not so much in the content of the pamphlet, since the source has already been published, as in the historiographic questions associated with it. The main interest was attracted by a part of the writing, which included a letter sent by Caspar von Münster to the landmaster Heinrich von Galen. It consists of three leaves of the total volume of the work. The subtitle "Volgendes schrewen hab ich ahn Herrn Meister gethan als mir mein Haus eingenommen ..." allows us to judge that this is a separate part of the pamphlet. Thus, the reason of its creating is pointed out as well - the occupying of Dünamünde, a fortress reported to the landmarshal. Was this an actual letter or was it only a part of the political pamphlet is one of the main questions. The pamphlet reveals its place and date: "Datum Segewald Freytag nach Exaudi" [Warhafftiger, kurtzer und wolgegründter bericht...]. Exaudi arrived on the sixth Sunday after Easter, which in 1556 was on April, 5 (according to the Julian calendar) ${ }^{2}$, i.e, the letter was to be dated by the first half of May. We have managed to find two letters of the landmarshal to the landmaster von Galen in the Secret Archives of the Prussian Cultural Heritage in Berlin [Jasper von Münster, Landmarshall des Deutschen Ordens in Livland...; Jasper of Münster to Henri of Galen]

\footnotetext{
${ }^{2}$ For details see [Huber].
} 
The registers of these documents are mentioned by S. Hartmann [Hartmann 2005, pp. 370, 376]. Its presence made it possible to ascertain that the letter as a part of the pamphlet was indeed written by Caspar von Münster. Nevertheless, there is a number of problems. One letter can be accurately identified as a copy from the ducal archive, as there is no signature [Hartmann 2005, p. 370]. As for the second letter [Hartmann 2005, p. 376], it has a signature, but there is another date "Freytag nach Jubilate", i.e., it was some days earlier than mentioned in the pamphlet. The rest of the text is completely identical, except for the first paragraph "Dem Hochwurdige (n) Großmechtihen fursten Herrn Herrn Heinrichen von Galen ... genedigen Herrn un (nd) Obersten gehorsamlich". In the letter from the archive this part is missing. It is difficult to say the reason of the difference in dates, as well as to precisely identify, whether the second document is an unsent original or a copy. It should be investigated further.

Apart from the above, Münster's pamphlet is of interest from the point of view of another participant in this process, the publisher. This essay was not the only one published in Johann Daubmann's printing house that took a position against the landmaster of the Teutonic Order and the new coadjutor which had at the same time an excusatory character. At the same time, another pamphlet under the title "Wunderbarliche Handlung dess jetzigen Meysters auss Leyfflandt unnd seines Stallbruders oder Coadjutorn Wilhelmen Fürstenberg unnd irem anhang ..." was published in the same printing house. The author of the pamphlet was Christophe Boddecker, a chancellor of the Order in Livonia, who succeeded Ochtern [Neitmann 2004, p. 202]. That is, in addition to the text of Caspar von Münster, another pamphlet on the same topic appeared in the same printing house. It is difficult to say whether it was explained only by economic reasons or by Albrecht of Brandenburg-Ansbach's order. Anyway, the publication of these pamphlets was beneficial to the duke in the context of his foreign policy and, perhaps, was conducive to the further rise Daubmann. In this regard, it seems necessary to say a few words about the printer and his contacts with the Duke of Prussia.

Little is known about the personality of Johann Daubmann. He was originally from Torgau in Saxony. The exact date of his birth is unknown [Arnoldt 1769, Bd. 2, p. 53; Bd. 3, p. 83; Allgemeine Deutsche Biographie 1876, p. 769]. There is evidence that the future Prussian printer started his career in Nuremberg. The Nuremberg period of Daubmann's activity was marked by a constant conflict with the local council, which sought to get book publishing under control. Despite the council's disapproval, he published a "Brochure ... about the murder of four children" [Lohmeyer 1896, p. 48; Arp 2004, p. 97]. Soon thereafter, Daubmann was imprisoned in the tower for eight days for selling banned books from Leipzig. According to some researchers, this was the work of Erasmus of Rotterdam [Lohmeyer 1896, p. 48]. Despite this, he soon published the "accusatory book" of margrave Albert Alcibiade against his opponents [Arp 2004, p. 98], which could be the reason for the arrest in April, 1554.

Further details of this matter are unknown, but some actions of this period are connected with his subsequent relocation to Koenigsberg. Thanks to the petition of the Duke of Prussia, Albrecht of Brandenburg-Ansbach, on May, 25 of the same year the Nurenberg Council agreed, that Daubmann could live in Prussia without losing his rights of Nurenberg's burgher. When on May, 28 there was made a search to identify all possible copies of the "accusatory book", Daubmann had already left the city [Lohmeyer 1896, p. 49]. The time of the beginning of his publishing activity in Prussia is uncertain as well. We 
know that by autumn Daubmann had been intensively engaged in printing. The publication of September, 1554 can be used as a confirmation [Arp 2004, p. 100; Abschied des Durchlauchtigsten Hochgeborenen Fürsten...]. However, the starting point of the printing house foundation in Koenigsberg is controversial. There is an opinion that he was invited by Albrecht of Brandenburg in 1553, even before the beginning of the process mentioned above, in order to publish the works of the professors of the University of Koenigsberg [Lohmeyer 1896, p. 49]. The most common perception is the end of May, 1554 [Thielen 1953, p. 110]. For us, however, the fact of contacts between the printer and the Duke of Prussia is especially important in this context. However, special support had been traced since the late 50s. At Daubmann's disposal had already been around 100 marks of annual increases from the ducal treasury [Arp 2004, 102]. Perhaps, he received an additional financial support as well.

At least, this can be assumed on the basis of Daubmann's notice of March 3, 1556 of receipt from Albrecht 100 guldens. It does not mention any conditions for the return of funds ['Albrecht von Brandenburg an Johann Daubmann']. At the same time, thanks to the Duke's of Prussia protection, the trade area of Johann Daubmann also expanded. In 1557, Albrecht of Brandenburg-Ansbach negotiated with Mikołaj Radziwill about the question, whether Daubmann could sell books in Vilno [Körber 1998, p. 224]. A year later, in May, 1558, Daubmann purchased a printing house, presumably from Jan Malecki, for 300 gulders (which shows that he had quite substantial funds just a few years after moving to Prussia) [Gollub 1929, p. 170]. In addition, he became competitive due to the fact that he had bought a bookshop and a paper mill [Arp 2004, p. 102].

It is difficult to say whether this support was connected with the publication of the political pamphlets of Christophe Boddecker and Caspar von Münster, however, this is quite possible, since after that Johann Daubmann published virtually nothing of a political nature.

At the same time, the pamphlet which belongs to the landmarshal of the Teutonic Order in Livonia, not only shows the connection between the political events, propaganda, printing activities, but is of great interest as a source study as well. This is mainly due to the fact that the letter written by the author of the text to the Livonian landmaster Heinrich von Galen is one of the sections of this pamphlet. Copies of this letter allow us to ask a few questions. Firstly, how did the two copies, which had been discussed above, come into the archives of the Duke. Were they created before sending the letter to landmaster, or had Münster a draft, which he later gave to the Duke, and later to the printer to create a copy. For what purpose were these two copies made? No less important is the answer to the question, whether there was any public reaction to this pamphlet. One of the reasons of this issue is the publication of this pamphlet in 1557 in the Daubman printing house as well, but in Latin. The question, among others, arises as to the intentions of this publication. However, these gaps do leave prospects for the further research.

\section{References}

Abschied des Durchlauchtigsten Hochgeborenen Fürsten vnnd Herrn Albrechten des Eltern Markgraffen zu Brandenburg in Preussen [etc.] Herzogen [etc.] darnach sich alle vnnd jedere ihrer F. G. Fürstenthumbs Pfarherrn vnvegerlich halten sollen... XXXIII Septembris ANNO M.D.LIII.Königsberg, Hans Daubmann's Print., 1554. Herzog August Bibliothek Wolfenbüttel [Duke August's Library of Wolfenbüttel], Codes 240.15 Quod. (1) and 216.13 Theol. (11). (In German) 
Albrecht von Brandenburg an Johann Daubmann [Albrecht of Brandenburg to Johann Daubmann]. Geheimes Staatsarchiv Preussischen Kulturbesitz zu Berlin [Secret archive of Prussian cultural heritage], EM 139 k 147, fol. 1. (In German).

Arnoldt D. H.Zusätze zu einer Historie der Königsbergischen Universität, nebst Nachrichten von dreyhundert und eilf preussischen Gelehrten [Additions to a history of the Konigsberg University, including news of three hundred and eleven Prussian scholars]. Vol.3. Königsberg, Print. House of Joh. Dan. Zeisens Witwe and Joh. Heinr. Hartungs Erbe, 1769, 204 p. (In German)

Allgemeine Deutsche Biographie [General German Biography]. Ed. by The Historical Commission of the Royal Academy of Science. Vol. 4. Leipzig, Dunckler and Humblot Publ., 1876, p. 769. (In German)

Arp I.Hans Daubmann und der Königsberger Buchdruck im 16 Jahrhundert - eine Profiskizze [Hans Daubmann and the Königsberg letterpress in the $16^{\text {th }}$ century - a prosperity]. Königsberger Buch- und Bibliotheksgeschichte [Königsberg's book and library history]. Kologne; Weimar; Vien, Böhlau Verlag, 2004, pp. 87-126. (In German)

Benker S., Kraus A. Geschichte Frankens bis zum Ausgang des 18. Jahrhunderts. Begründet von Max Spindler [History of Franconia until the end of the $18^{\text {th }}$ century. Collected by Max Spindler]. Eds S. Benker, A. Kraus. Munich, Beck Verlag, 1997, 1466 p. (In German)

Bergegrün A. Bibliothek livländischer Geschichte. Bd. II. Christof von Meklenburg [Library of Livonian history. Vol. II. Christof von Mecklenburg]. Ed. by Seraphim E. Revel. Verlag von Franz Kluge, 1898, 324 p. (In German)

Bessudnov D. A. Vrag moego vraga politicheskaia pozitsiia landmarshala Jaspera von Munstera nakanune Livonskoi voiny [The enemy of my enemy: the political position of Landmarshal Jasper von Münster on the eve of the Livonian War]. Křžzovatky Slovanů [Intersections Slavs]. Praha, Pavel Mervart Print., 2015, pp. 147-152. (In Russian)

Bohl Ju. von. Caspar von Münster's, Landmarschalls des D. O. in Livland, Verteidigung Schrift 1556 [Caspar of Münster, Landmarshals of the Teutonic order in Livonia. A defense Memorandum of 1556]. Mitteilungen aus dem Gebiete der Geschichte und Alterthumskunde der Ostsee - Provinzen Russlands [Communications from the history and antiquities of the Baltic Sea - provinces of Russia]. Vol. 10. Riga, Nikolai Kymmel's Buchhandlung Print., 1865, pp. 143-160. (In German)

Fligge J.R. Herzog Albrecht von Preussen und der Osiandrismus 1522-1568 [Duke Albrecht of Prussia and Osiandrism 1522-1568]. PhD Diss. Bonn, Rheinish Friedrich-Wilhelms-University Press, 1972, 1078 p. (In German)

Gause F. Die Geschichte der Stadt Königsberg in Preussen [History of the city of Königsberg in Prussia]. Munich, Gräfe und Unzer Verlag, 1968, 243 p. (In German)

Gollub H. Die beiden Buchdrucker und Erzpriester Maletius [The two bookprinters and archpriest Maletius]. Königsberger Beiträge [Königsberg's reports]. Koenigsberg, Gräfe and Unzer Print., 1929, pp. 159-180. (In German)

Grimm H.Die Buchführer des deutschen Kulturbereichs und ihre Niederlassungsorte in der Zeitpanne 1490 bis um 1550 [The bookkeepers of the German cultural sphere and their settlements in the period from 1490 to around 1550]. Archiv für die Geschichte des Buchwesens [Archive for the history of bookkeeping], 1967, vol. 7, pp. 1153-1771. (In German)

Fenske L., Militzer K.Ritterbrüder im livländischen Zweig des Deutschen Ordens [Brotherhood of the Livonian branch of the Teutonic Order]. Kologne, Böhlau Publ., 1993, 956 p. (In German)

Hartmann S. Neue Quellen zur livländischen Koadjutorfehde 1555/6 [New sources of the Livonian coadjutor's feud]. Aus der Geschichte Alt-Livlands [From the history of Old Livonia]. Münster, Lit Verlag, 2004, pp. 275-307. (In German)

Herzog Albrecht und Livland (1551-1557). Regesten aus Herzogliches Briefarchiv und den Ostpreussen Folianten [Duke of Albrecht and Livonia (1551-1557). Register from the Herzogliches Briefarchiv and the Ostprussen Folianten] (=Veröffentlichungen aus den Archiven Preußischer Kulturbesitz) [Publications from the Archives Prussian Cultural Heritage]. Vol.57. Ed. by S. Hartmann Kologne; Weimar; Vien, Böhlau Publ., 2005, 562 p. (In German)

Huber T.W. Ostern bewegliche Tage [Easter moving days] (in German). Available at: http://www.nvf.ch/zw/ ostern.asp?Jahr=1556\&submitButtonName=Zeigen (accessed 28.12.2016).

Jasper von Münster, Landmarshall des Deutschen Ordens in Livland an Heinrich von Galen [Jasper of Münster, Landmarshall of the Teutonic Order in Livonia to Genrich von Galen]. Geheimes Staatlisches Archiv Preußischer Kulturbesitz [Secret archive of Prussian cultural heritage], HBA D, no. 1906. (In German).

Jasper von Münster an Heinrich von Galen [Jasper of Münster to Henri of Galen]. Geheimes Staatlisches Archiv Preußischer Kulturbesitz [Secret archive of Prussian cultural heritage], HBA D, no. 1910/2. (In German). 
Kreem J. Netzwerke um Jasper von Munster. Der Deutsche Orden während der livländischen Koadjutorfehde im Jahre 1556 [Networks around Jasper von Munster. The Teutonic Order during the Livonian Koadjutorfehde in 1556.]. Ordines Militares [Military orders], 2014, vol. 19, pp. 73-86.

Körber E.-B.Öffentlichkeiten der Frühen Neuzeit. Teilnehmer, Formen, Institutionen und Entscheidungen öffentlicher Kommunikation im Herzogtum Preußen von 1525 bis 1618 [Early modernity. Participants, forms, institutions and decisions of public communication in the duchy of Prussia from 1525 to 1618]. Berlin, de Gruyter Publ., 1998, 536 p. (In German)

Lohmeyer K. Geschichte des Buchdrucks und des Buchhandels im Herzogtum Preussen [History of book printing and book trade in the Duchy of Prussia]. Archiv für Geschichte des Deutsche Buchhandel [Archive for the history of the German book trade], 1896, vol. 18, p. 48. (In German)

Luksaite I. Das deutsche protestantisches Buch des 16 und 17 Jahrhunders in Großfürstentum Litauen [The German Protestant book of the $16^{\text {th }}$ and $17^{\text {th }}$ centuries in the Grand-Duchy of Lithuania]. NordostArchiv. Neue Folge [Northeast Archives. New edition], 1995, vol. 1, pp. 143-154 (In German)

Lyublinskiy V. S. Na zare knigopechataniya [At the dawn of a bookprinting]. St. Petersburg, Russian National Library Publ., 2006, 166 p. (In Russian)

Merkel G. Die Vorzeit Lieflands. Ein Denkmahl des Pfaffen- und Rittergeistes [The early History of Livonia. A monument to the priestly and knightly spirit]. Berlin, Vossische Buchhandlung Publ., 1807, 422 p. (In German)

Mol J. Traitor to Livonia? The Teutonic Orders' landmarshall Jasper van Münster and his action at the outset of the Livonian crisis, 1554-1556. Ordines Militares [Military orders], 2014, vol. 19, pp. 205-240.

$\mathrm{Mol}$ J. A. Vechten, bidden en verpflegen. Opstellen over de ridderorden in de Noordelijke Nederlanden [Fighting, praying and nursing. Drawing on the orders of the Northern Netherlands]. Utrecht, Hilversum Verloren Publ., 2011, 367 p. (In Dutch)

Monumenta Livoniae Antiquae [Livonian Ancient Monuments]. Vol.5. Riga; Leipzig, Eduard Frantzen's Verlag - Comptoir, 1847, 749 p.

Münster J.v. Warhafftiger, kurtzer und wolgegründter bericht, des Ehrwirdigen.... Herren Caspar v. Münster, Teutsches Ordens Landtmarschalchs zu Leyfflandt. Ed. by Daubmann H. Koenigsberg, 1556. Rossiyskaya Natsionalnaya Biblioteka [National Library of Russia] (RNB). Rossica Department, no. 13.6.2.173. (In German)

Neitmann K. Spätzeit des Deutschen Ordens. Aus der Geschichte Alt-Livlands. Festschrift für Heinz von zur Mühlen zum 90. Geburtstag [From the history of Old Livonia. A Festschrift for Heinz von zur Mühlen on his $90^{\text {th }}$ birthday]. Münster, Lit Verlag, 2004, pp. 185-237. (In German)

Olewnik J.Polsko-Pruski plan inkorporacji Inflant do monarchii Jagiellonskiej z lat 1552-1555 i jego pierwsze stadium realizacji [Olewnik J.Polsko-Pruski plan to incorporate of Livonia into the Jagiellonian monarchy from the years 1552-1555 and his first stage of implementation]. Komunikaty mazursko-warminskie. Kwartalnik [Mazursko-warminskie messages Quarterly], 1979, no. 4, pp. 393408. (In Polish)

Popov V.E., Filyushkin A. I. "Voyna koadyutorov" i Pozvolskie soglasheniya 1557 g. [Coadjutors war and the compact of Pozwol 1557]. Studia Slavica et Balcanica Petropolitana [Slavic and Balkan studies], 2009, no. 1, pp. 151-185. (In Russian)

Rasmussen K.Die livländische Kreis 1554-1561 [The Livonian circle 1554-1561]. Kopenhavn, Universitetsforlaget [University of Copenhagen Publ.], 1973, 241 p. (In German)

Renner J.Livländische Historien 1556-1561. Zum ersten Mal nach der Urschrift [Livonian Histories 15561561. For the first time after the original]. Ed. by P. Karstedt. Lübeck, Max Schmidt-Römhild Publ., 1953, 150 p. (In German)

Russow B. Livländischer Chronik [Livonian chronicle]. Reval, F. J. Koppelson Print., 1845, 348 p. (In German) Thielen P. G. Die Kultur am Hofe Herzog Albrecht von Preußen (1525-1568) [The culture at the court Duke Albrecht of Prussia (1525-1568)]. Göttingen, "Musterschmidt" wissenschaftlicher Verlag, 1953, 256 p. (In German)

Thomae Hiärn's Ehst-. Liv- und Lettlaendische Geschichte [Thomas Hiern's Ehst-, Liv- and Latvian history]. Ed. by C. Napierski. Monumenta Livoniae Antiquae [Livonian Ancient Monuments]. Vol.1. Riga; Dorpat; Leipzig, Verlag von Eduard Frantzen Buchhandlung, 1835, 444 p. (In German)

Weber D. Nemetskiy orden $v$ Livonii ot Reformatsii do sekulyarizatsii [Teutonic order in Livonia in the time of Reformation and secularization]. Phd Diss. St. Petersburg, Ivanovo State University, 2014, pp. 212 232. (In Russian) 